\title{
Factors Affecting the Customer Loyalty of Tokopedia E-Commerce
}

\author{
Wianadhira Nur Hasna ${ }^{\# 1}$, Indira Rachmawati ${ }^{* 2}$

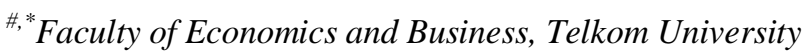 \\ Jl. Gegerkalong Hilir No. 47, Bandung 40152
}

\begin{abstract}
This research aims to recognize any factors that might affect the customer loyalty on Tokopedia with its related variables such as service user interface, service information quality, perceived security, e-commerce service feedback, perceived privacy, perceived risk, perception of website quality, e-customer satisfaction, and e-customer trust. The process of collecting data uses a questionnaire with a purposive sampling method and 385 respondents are Tokopedia users. The data analysis technique used in this research is SEM-PLS (Partial Least Square). The result of this research mentions that variables of e-commerce service user interface, perceived privacy, perceived risk, perception of website quality influence the variables of e-commerce satisfaction and ecommerce trust while e-commerce service information quality variable only has a positive influence on ecommerce satisfaction variable. On the other hand, e-commerce satisfaction does not have a positive influence on e-commerce customer loyalty while e-commerce trust positively influences e-customer loyalty.
\end{abstract}

Keywords - E-commerce, Indonesia, Satisfaction, Trust, Loyalty

\section{InTRODUCTION}

The advancement of internet from year to year is no longer doubted for it is not something people would consider taboo anymore. Internet is able to open up human horizons and act as a media to provide lots of information about anything that might be happening in different parts of the world ${ }^{[11]}$.

Internet is defined as the widest network in information technology system that allows many devices around the world to stay connected ${ }^{[18]}$. The user of internet in Indonesia has been increasing every year. Quoting from The Association of Indonesia Internet Service Providers ${ }^{[2]}$ in 2020 , there are 196,71 million people of Indonesia who actively use the internet from the total of population of 266,91 million people and the percentage number reaches $73,7 \%$.

The high adoption level of e-commerce in Indonesia can be the perfect opportunity for entrepreneurs and business men to channel their interaction with customers. As reported from statista.com ${ }^{[20]}$, the high distribution of e-commerce users in Indonesia is found in Jakarta, Bandung, Makassar, Medan and Surabaya city. In fact, there are various e-commerce platforms that can be used for online transaction in Indonesia. In 2019, databoks ${ }^{[13]}$ found that the transaction value of Tokopedia in 2018 reached $\$ 5.9$ billion while the transaction value for Shopee and Bukalapak reached $\$ 3,9$ billion and $\$ 1,9$ billion. It concludes that Tokopedia has the highest transaction value compared to Shopee and Bukalapak.

Several researches show that there are various factors affecting customer loyalty on one company. The research conducted in 2011 shows that significant loyalty is affected by customer satisfaction ${ }^{[3]}$. Research in 2018 had also done the same research and found out some factors that significantly affect the customer loyalty ${ }^{[19]}$. They are user interface, information quality, perceived security, and customer feedback. Moreover, some other studies shows that security and privacy influence trust and customer satisfaction ${ }^{[22][1][12]}$.

According to the phenomenon and previous study, this research will examine whether these factors might affect Tokopedia customer loyalty. Factors that will be used in examining is based on the previous research [19][22].

\section{LITERATURE REVIEW}

Marketing management is the art and science of choosing target markets and getting, keeping, and growing customers through creating, delivering, and communicating superior customer value ${ }^{[15]}$. Other than that, 
DOI: $\underline{10.51386 / 25815946 / \mathrm{ijsms}-\mathrm{v} 4 \mathrm{i} 3 \mathrm{p} 118}$

Volume: 4 Issue: 3

May to June 2021

www.ijjsmsjournal.org

marketing is a method of creating relationships with customers ${ }^{[6]}$. User interface is defined as a channel where customer is able to perform direct communication with the electronic service provider ${ }^{[9]}$.

The quality of information is the amount of information that is available regarding the attributes of one product brand, or company that will help customer to evaluate one particular object ${ }^{[8]}$. Security is interpreted as a perception felt by the customers where they can feel safe about their personal information usage and that it will not be used inappropriately by irresponsible people during the online transaction process ${ }^{[7]}$.

Customer feedback is defined as customer communication regarding one product or service ${ }^{[4]}$. Perceived privacy is how far the customers believe that they have the right to control the collection and usage of their personal information including when giving out the information to another people ${ }^{[16]}$.

Perceived risk is an uncertainty faced by the customers when they are not able to foresee any possibilities that will happen from their current purchase decision ${ }^{[21]}$. In an online context, customers' satisfaction can be seen from the comparison of their experience shopping from a traditional retail shop to an electronic retail shop $^{[5]}$.

Trust can be interpreted as all knowledge possessed by the customers and all conclusion they have about object, attribute, and benefit ${ }^{[17]}$. Loyalty is a commitment to purchase and to support their favorite product or service in the future even a change of situation as well as the marketing effort might cause the customers to take turn to another company ${ }^{[14]}$.

These are the list of possible hypothesis based on previous research:

H1: E-commerce Service User Interface has significant and positive influence on E-commerce Satisfaction.

H2: E-commerce Service User Interface has significant and positive influence on E-commerce Trust.

H3: E-commerce Service Information Quality has significant and positive influence on E-commerce Satisfaction.

H4: E-commerce Service Information Quality has significant and positive influence on E-commerce Trust.

H5: Perceived Security has significant and positive influence on E-commerce Satisfaction.

H6: Perceived Security has significant and positive influence on E-commerce Trust.

H7: E-commerce Customer Feedback has significant and positive influence on E-commerce Satisfaction.

H8: E-commerce Customer Feedback has significant and positive influence on E-commerce Trust.

H9: Perceived Privacy has significant and positive influence on E-commerce Satisfaction.

H10: Perceived Privacy has significant and positive influence on E-commerce Trust.

H11: Perceived Risk has significant and positive influence on E-commerce Satisfaction.

H12: Perceived Risk has significant and positive influence on E-commerce Trust.

H13: Perception of Website Quality has significant and positive influence on E-commerce Satisfaction.

H14: Perception of Website Quality has significant and positive influence on E-commerce Trust.

H15: E-commerce Satisfaction has significant and positive influence on E-commerce Customer Loyalty.

H16: E-commerce Trust has significant and positive influence on E-commerce Customer Loyalty.

\section{III.METHOD}

This research uses a purposive sampling taken from individual who has done three or more transactions on Tokopedia in the past year. Data that has been collected is as many as 385 respondents. The answers are checked and measured by using likert scale. Furthermore, data is then processed using PLS-SEM which aims to test the existence of predictive relation or influence among the construct. PLS approach itself is especially used for dependent variable with independent variable involvement ${ }^{[10]}$.

Model evaluation in PLS consists of two steps. The first one is outer model evaluation or measurement model and the second one is inner model evaluation or structural measurement ${ }^{[10]}$. There is reflective and formative measurement in outer model. Evaluation on reflective model indicator includes a tight check on: (1) individual item reliability, (2) internal consistency or construct reliability and (3) average variance extracted and (4) discriminant validity. The first three measurements are categorized into convergent validity. While on formative measurement model evaluation, there are (1) content specification which is related to the scope of lateen construct that will be measured, (2) specification indicator is used to identify and define the said indicator, 
DOI: $\underline{10.51386 / 25815946 / \mathrm{ijsms}-\mathrm{v} 4 \mathrm{i} 3 \mathrm{p} 118}$

Volume: 4 Issue: 3

May to June 2021

www.ijsmsjournal.org

(3) reliability indicator relates to the indicator importance scale that shapes the construct with its weight indicator of 0.2 minimum or significant, (4) external validity gives a warranty that every indicator created will be included in the model ${ }^{[10]}$.

\section{IV.RESULTS}

The result of this research uses Smart PLS 3.0 with the following result:

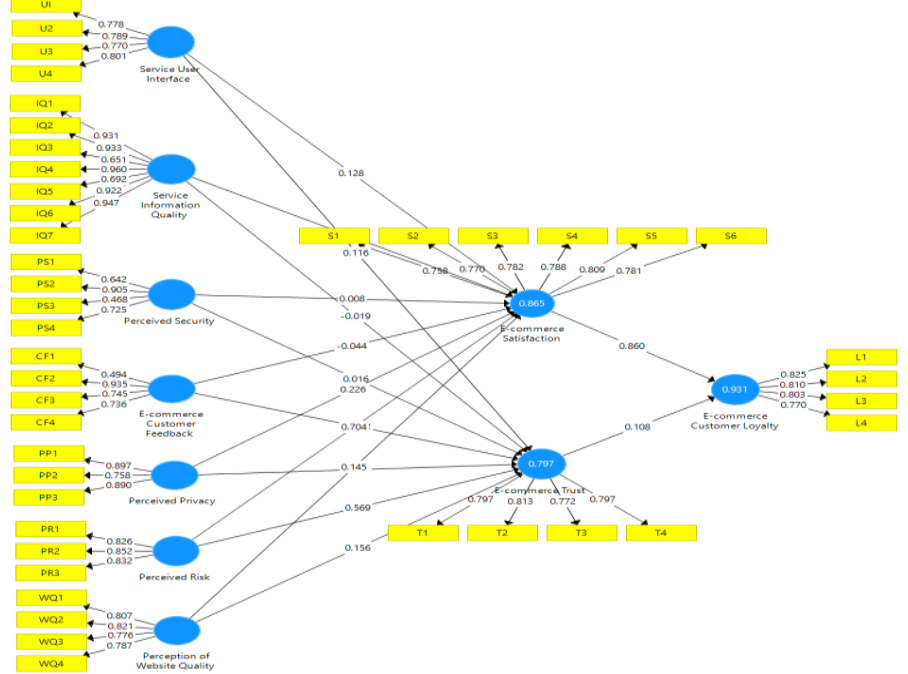

Fig 1. Model Partial Least Square

\section{A. Outer Model} as follows:

Loading factor value is $\geq 0.7$ which is considered ideal and valid. According to the data, the results are

Table 1 Convergent Validity

\begin{tabular}{|c|c|c|}
\hline Variable & Item & Loading Factor \\
\hline \multirow{4}{*}{ Service User Interface } & U1 & 0.778 \\
\hline & $\mathrm{U} 2$ & 0.789 \\
\hline & U3 & 0.769 \\
\hline & $\mathrm{U} 4$ & 0.803 \\
\hline \multirow{5}{*}{ Service Information Quality } & IQ1 & 0.955 \\
\hline & IQ2 & 0.963 \\
\hline & IQ4 & 0.973 \\
\hline & IQ6 & 0.953 \\
\hline & IQ7 & 0.972 \\
\hline \multirow[t]{2}{*}{ Perceived Security } & PS2 & 0.946 \\
\hline & PS4 & 0.724 \\
\hline \multirow{3}{*}{ Customer Feedback } & $\mathrm{CF} 2$ & 0.920 \\
\hline & CF3 & 0.767 \\
\hline & CF4 & 0.755 \\
\hline \multirow{3}{*}{ Perceived Privacy } & PP1 & 0.899 \\
\hline & PP2 & 0.756 \\
\hline & PP3 & 0.891 \\
\hline \multirow{3}{*}{ Perceived Risk } & PR1 & 0.838 \\
\hline & PR2 & 0.848 \\
\hline & PR3 & 0.825 \\
\hline \multirow{4}{*}{ Perception of Website Quality } & WQ1 & 0.806 \\
\hline & WQ2 & 0.822 \\
\hline & WQ3 & 0.774 \\
\hline & WQ4 & 0.788 \\
\hline \multirow{4}{*}{ E-Customer Satisfaction } & $\mathrm{S} 1$ & 0.780 \\
\hline & $\mathrm{S} 2$ & 0.819 \\
\hline & S3 & 0.841 \\
\hline & S4 & 0.785 \\
\hline \multirow[b]{3}{*}{ E-Customer Trust } & $\mathrm{T} 1$ & 0.796 \\
\hline & $\mathrm{T} 2$ & 0.813 \\
\hline & T3 & 0.772 \\
\hline
\end{tabular}




\begin{tabular}{|l|c|c|}
\cline { 2 - 3 } & T4 & 0.797 \\
\hline \multirow{4}{*}{ E-Customer Loyalty } & L1 & 0.809 \\
\cline { 2 - 3 } & L2 & 0.808 \\
\cline { 2 - 3 } & L3 & 0.807 \\
\cline { 2 - 3 } & L4 & 0.783 \\
\hline
\end{tabular}

According to the table above, the last convergent validity result shows that each variable has $\geq 0.700$ of loading factor value hence it is valid and that every indicator is the creator factor from its latent variable.

Table 2 Average Variant Extracted (AVE)

\begin{tabular}{|c|c|}
\hline Variable & $\begin{array}{c}\text { Average Variance Extracted } \\
\text { (AVE) }\end{array}$ \\
\hline Service User Interface (UI) & 0.616 \\
\hline Service Information Quality (IQ) & 0.927 \\
\hline Perceived Security (PS) & 0.709 \\
\hline Customer Feedback (CF) & 0.668 \\
\hline Perceived Privacy (PP) & 0.724 \\
\hline Perceived Risk (PR) & 0.701 \\
\hline Perception of Website Quality (WQ) & 0.636 \\
\hline E-Customer Satisfaction (S) & 0.650 \\
\hline E-Customer Trust (T) & 0.632 \\
\hline E-Customer Loyalty (L) & 0.643 \\
\hline
\end{tabular}

Based on the second table, all variables have $>0.5$ of AVE value. This shows that variable used in this research has a good convergent validity score.

Table 3. Discriminant Validity

\begin{tabular}{|c|c|c|c|c|c|c|c|c|c|c|}
\hline & $\mathbf{C F}$ & $\mathbf{L}$ & $\mathbf{S}$ & $\mathbf{T}$ & $\mathbf{P P}$ & $\mathbf{R R}$ & PS & WQ & IQ & $\mathbf{U}$ \\
\hline CF2 & 0.920 & -0.056 & -0.076 & -0.050 & 0.003 & -0.038 & 0.451 & -0.020 & -0.019 & -0.029 \\
\hline CF3 & 0.767 & 0.006 & -0.022 & -0.005 & 0.057 & -0.008 & 0.411 & 0.042 & -0.020 & -0.013 \\
\hline CF4 & 0.755 & -0.025 & -0.047 & -0.028 & $0.005^{-}$ & -0.014 & 0.418 & 0.011 & -0.020 & -0.035 \\
\hline IQ1 & -0.025 & 0.566 & 0.667 & 0.674 & 0.484 & 0.773 & -0.082 & 0.541 & 0.955 & 0.445 \\
\hline IQ2 & -0.018 & 0.531 & 0.634 & 0.645 & 0.485 & 0.762 & -0.098 & 0.483 & 0.963 & 0.389 \\
\hline IQ4 & -0.032 & 0.599 & 0.705 & 0.714 & 0.522 & 0.837 & -0.091 & 0.539 & 0.973 & 0.418 \\
\hline IQ6 & -0.009 & 0.529 & 0.628 & 0.634 & 0.472 & 0.735 & -0.077 & 0.498 & 0.953 & 0.428 \\
\hline IQ7 & -0.026 & 0.556 & 0.662 & 0.674 & 0.488 & 0.789 & -0.085 & 0.513 & 0.972 & 0.396 \\
\hline L1 & -0.024 & 0.809 & 0.677 & 0.696 & 0.415 & 0.800 & -0.079 & 0.578 & 0.547 & 0.499 \\
\hline L2 & -0.044 & 0.808 & 0.634 & 0.749 & 0.430 & 0.787 & -0.044 & 0.565 & 0.469 & 0.467 \\
\hline L3 & -0.001 & 0.807 & 0.781 & 0.782 & 0.462 & 0.604 & -0.102 & 0.574 & 0.420 & 0.528 \\
\hline L4 & -0.074 & 0.783 & 0.767 & 0.780 & 0.631 & 0.580 & -0.072 & 0.546 & 0.428 & 0.456 \\
\hline PP1 & 0.034 & 0.466 & 0.596 & 0.537 & 0.899 & 0.487 & 0.005 & 0.370 & 0.467 & 0.357 \\
\hline PP2 & -0.020 & 0.584 & 0.622 & 0.588 & 0.756 & 0.453 & 0.008 & 0.435 & 0.373 & 0.392 \\
\hline PP3 & 0.010 & 0.490 & 0.619 & 0.560 & 0.891 & 0.505 & 0.025 & 0.375 & 0.458 & 0.368 \\
\hline PR1 & -0.034 & 0.599 & 0.706 & 0.715 & 0.517 & 0.838 & -0.092 & 0.537 & 0.968 & 0.417 \\
\hline PR2 & -0.008 & 0.783 & 0.650 & 0.678 & 0.451 & 0.848 & -0.064 & 0.566 & 0.559 & 0.475 \\
\hline PR3 & -0.035 & 0.783 & 0.616 & 0.729 & 0.455 & 0.825 & -0.068 & 0.549 & 0.490 & 0.429 \\
\hline PS2 & 0.402 & -0.090 & -0.113 & -0.076 & 0.010 & -0.068 & 0.946 & -0.111 & -0.079 & -0.137 \\
\hline PS4 & 0.551 & -0.063 & -0.042 & -0.051 & 0.020 & -0.100 & 0.724 & -0.059 & -0.078 & -0.042 \\
\hline S1 & -0.030 & 0.785 & 0.780 & 0.767 & 0.447 & 0.595 & -0.123 & 0.588 & 0.425 & 0.524 \\
\hline $\mathbf{S 2}$ & -0.114 & 0.759 & 0.819 & 0.759 & 0.670 & 0.566 & -0.105 & 0.559 & 0.430 & 0.493 \\
\hline
\end{tabular}


DOI: $\underline{10.51386 / 25815946 / \mathrm{ijsms}-\mathrm{v} 4 \mathrm{i} 3 \mathrm{p} 118}$

Volume: 4 Issue: 3

May to June 2021

www.ijsmsjournal.org

\begin{tabular}{|l|l|l|l|l|l|l|l|l|r|r|} 
S3 & -0.018 & 0.677 & $\mathbf{0 . 8 4 1}$ & 0.755 & 0.720 & 0.581 & -0.025 & 0.511 & 0.515 & 0.499 \\
\hline S4 & -0.064 & 0.659 & $\mathbf{0 . 7 8 5}$ & 0.795 & 0.493 & 0.796 & -0.080 & 0.559 & 0.847 & 0.456 \\
\hline T1 & -0.012 & 0.799 & 0.683 & $\mathbf{0 . 7 9 6}$ & 0.365 & 0.682 & -0.081 & 0.589 & 0.452 & 0.482 \\
\hline T2 & -0.018 & 0.814 & 0.812 & $\mathbf{0 . 8 1 3}$ & 0.591 & 0.630 & -0.070 & 0.549 & 0.462 & 0.539 \\
\hline T3 & -0.051 & 0.711 & 0.760 & $\mathbf{0 . 7 7 2}$ & 0.667 & 0.589 & -0.021 & 0.505 & 0.459 & 0.427 \\
\hline T4 & -0.060 & 0.657 & 0.779 & $\mathbf{0 . 7 9 7}$ & 0.494 & 0.789 & -0.072 & 0.567 & 0.845 & 0.459 \\
\hline U2 & -0.042 & 0.475 & 0.482 & 0.479 & 0.312 & 0.425 & -0.125 & 0.482 & 0.388 & $\mathbf{0 . 7 8 9}$ \\
\hline U3 & -0.027 & 0.438 & 0.417 & 0.415 & 0.327 & 0.377 & -0.113 & 0.437 & 0.311 & $\mathbf{0 . 7 6 9}$ \\
\hline U4 & -0.029 & 0.507 & 0.534 & 0.524 & 0.394 & 0.447 & -0.059 & 0.552 & 0.387 & $\mathbf{0 . 8 0 3}$ \\
\hline UI & -0.007 & 0.482 & 0.474 & 0.457 & 0.341 & 0.392 & -0.092 & 0.427 & 0.257 & $\mathbf{0 . 7 7 8}$ \\
\hline WQ1 & 0.042 & 0.525 & 0.512 & 0.517 & 0.379 & 0.532 & -0.083 & $\mathbf{0 . 8 0 6}$ & 0.436 & 0.415 \\
\hline WQ2 & 0.056 & 0.588 & 0.567 & 0.578 & 0.366 & 0.521 & -0.081 & $\mathbf{0 . 8 2 2}$ & 0.437 & 0.423 \\
\hline WQ3 & -0.051 & 0.562 & 0.540 & 0.549 & 0.347 & 0.522 & -0.073 & $\mathbf{0 . 7 7 4}$ & 0.433 & 0.566 \\
\hline WQ4 & -0.052 & 0.572 & 0.572 & 0.570 & 0.391 & 0.525 & -0.106 & $\mathbf{0 . 7 8 8}$ & 0.403 & 0.535 \\
\hline
\end{tabular}

Based on the third table, discriminant validity result shows that every variable has the biggest cross loading value on created variable compared to another variable. It concludes that indicators used in this research are the great discriminant validity.

Table 4 Reliability Test, Cronbach \& Composite

\begin{tabular}{|c|c|c|}
\hline Variable & Cronbach's Alpha & Composite Reliability \\
\hline Service User Interface (UI) & 0.793 & 0.865 \\
\hline Service Information Quality (IQ) & 0.980 & 0.985 \\
\hline Perceived Security (PS) & 0.730 & 0.827 \\
\hline Customer Feedback (CF) & 0.776 & 0.857 \\
\hline Perceived Privacy (PP) & 0.806 & 0.887 \\
\hline Perceived Risk (PR) & 0.786 & 0.875 \\
\hline Perception of Website Quality (WQ) & 0.809 & 0.875 \\
\hline E-Customer Satisfaction (S) & 0.820 & 0.881 \\
\hline E-Customer Trust (T) & 0.806 & 0.873 \\
\hline E-Customer Loyalty (L) & 0.815 & 0.878 \\
\hline
\end{tabular}

Reliability is related to trust value, capability, consistency, or the stability of one measurement. Internal consistency reliability from Cronbach's Alpha and Composite Reliability (CR) value with the limit of $>0.7$ is acceptable while $>0.8$ is satisfactory ${ }^{[10]}$. According to the table, all variables have cronbach alpha and composite reliability value of $>0.7$. This shows that variable construct has a good reliability score.

\section{B. Inner Model}

Table 5 R-Square

\begin{tabular}{|l|r|}
\hline \multicolumn{1}{|c|}{ Variable } & $\boldsymbol{R}$-Square \\
\hline E-customer Satisfaction & 0.781 \\
\hline E-customer Trust & 0.797 \\
\hline E-customer Loyalty & 0.883 \\
\hline
\end{tabular}

In evaluating the r-square value, it can be seen from the variability magnitude of endogenous variables which can be explained by exogenous variables consisting of three classification criteria such as $0.57,0.33$, and 0.19 as substantial, moderate, and weak. Based on r-square table, it shows that the r-square value of e-commerce satisfaction variable reaches 0.781 which is included in a good category. This says that as much as $78,1 \%$ 
percentage of e-customer satisfaction can be explained by service user interface, service information quality, perceived security, customer feedback, perceived privacy, perceived risk, and perception of website quality. In the meantime, e-customer trust variable has $r$-square values as much as 0.797 which is also included in a good category. For further result, there is $79,7 \%$ percentage of e-commerce trust that can be explained by service user interface, service information quality, perceived security, customer feedback, perceived privacy, perceived risk, and perception of website quality. Furthermore, e-customer loyalty has an r-square value as much as 0,883 which is in a good category. This shows that $88,3 \%$ percentage of e-commerce trust is explained by e-customer satisfaction and e-commerce trust.

R-square in PLS model can be evaluated by looking at q-square predictive relevance for variable model. Q-square value that is more than 0 (zero) implies that the model has a predictive relevance value yet when qsquare value is below 0 (zero), it means that the model has less predictive relevance value. The following paragraph is the measurement result of q-square value.

$Q$-Square $=1-\left(1-\mathrm{R}^{2} 1\right) \times\left(1-\mathrm{R}^{2} 2\right) \times\left(1-\mathrm{R}^{2} 3\right)$

$=1-(1-0.781) \times(1-0.797) \times(1-0.883)$

$=1-(0.219) \times(0.203) \times(0.117)$

$=1-(0.005201)$

$=0.994799$ or $99.5 \%$

According to the measurement result, the q-square value obtained is $99,5 \%$ which is included in a good category. This result explains that the diversity of data used in this research is as much as $99,5 \%$ while the rest of $0,5 \%$ is explained by another variable outside of this research.

Table 6. Hypothesis Testing

\begin{tabular}{|c|c|c|c|c|c|}
\hline Variable & Original Sample & T Statistics & T Table & $\operatorname{Sig}\left(\mathbf{P}_{\text {value }}\right)$ & Result \\
\hline UI $\rightarrow S$ & 0.137 & 3.814 & 1.966 & 0.000 & Accepted \\
\hline UI $\rightarrow \mathrm{T}$ & 0.117 & 3.319 & 1.966 & 0.000 & Accepted \\
\hline IQ $->S$ & 0.087 & 1.787 & 1.966 & 0.037 & Accepted \\
\hline IQ $>\mathrm{T}$ & -0.006 & 0.140 & 1.966 & 0.444 & Rejected \\
\hline PS $->S$ & -0.009 & 0.245 & 1.966 & 0.403 & Rejected \\
\hline PS $\rightarrow \mathrm{T}$ & 0.016 & 0.568 & 1.966 & 0.285 & Rejected \\
\hline $\mathrm{CF} \rightarrow \mathrm{S}$ & -0.052 & 1.542 & 1.966 & 0.062 & Rejected \\
\hline $\mathrm{CF} \rightarrow \mathrm{T}$ & -0.032 & 1.057 & 1.966 & 0.146 & Rejected \\
\hline $\mathrm{PP} \rightarrow \mathrm{S}$ & 0.352 & 8.658 & 1.966 & 0.000 & Accepted \\
\hline $\mathrm{PP} \rightarrow \mathrm{T}$ & 0.225 & 6.283 & 1.966 & 0.000 & Accepted \\
\hline PR $>S$ & 0.323 & 6.011 & 1.966 & 0.000 & Accepted \\
\hline PR $\rightarrow \mathrm{T}$ & 0.559 & 10.449 & 1.966 & 0.000 & Accepted \\
\hline WQ $>S$ & 0.181 & 4.737 & 1.966 & 0.000 & Accepted \\
\hline WQ $\rightarrow \mathrm{T}$ & 0.157 & 4.545 & 1.966 & 0.000 & Accepted \\
\hline S $\rightarrow$ L & -0.024 & 0.306 & 1.966 & 0.380 & Rejected \\
\hline $\mathrm{T} \rightarrow \mathrm{L}$ & 0.962 & 12.783 & 1.966 & 0.000 & Accepted \\
\hline
\end{tabular}

Referring to Table 6., a conclusion found based on hypothesis testing by comparing t-statistic result and t-table (1.966) with significance level of 5\% $(0,05)$ which means there are 6 rejected hypothesis while the other 10 are accepted. The rejected ones are H4, H5, H6, H7, H8, and H15. The other 10 are accepted according to the criteria from the hypothesis testing.

\section{Discussion}

According to the $1^{\text {st }}$ hypothesis $(\mathrm{H} 1)$ testing result, e-commerce service user interface has a positive and significant influence on e-commerce satisfaction that is proven by the result of $t$-statistic $>\mathrm{t}$-table $(3.814>$ 1.966) and p-value of $0.000<0,05$. What is shown in the result fits the previous research done by Nasimi et al. (2018). It concludes that e-commerce service user interface indicator is as easy as using e-commerce, interesting information and visual, and the search effectiveness on Tokopedia may affect the satisfaction of the customers. 
DOI: $\underline{10.51386 / 25815946 / \text { ijsms-v4i3p118 }}$

Volume: 4 Issue: 3

May to June 2021

www.ijjsmsjournal.org

The $2^{\text {nd }}$ hypothesis $(\mathrm{H} 2)$ testing result shows that e-commerce service user interface has positive and significant influence on e-commerce trust proven by the result of $\mathrm{t}$-statistic value that is more than $\mathrm{t}$-table value; t-statistic $>$ t-table $(3.319>1.966)$ and p-value of $0.000<0.05$. The result suits best to Nasimi's previous research (2018). It concludes that e-commerce service user interface indicator is as easy as using e-commerce, interesting information and visual, and the search effectiveness on Tokopedia may affect the satisfaction of the customers.

Referring to the $3^{\text {rd }}$ hypothesis $(\mathrm{H} 3)$, e-commerce service information quality has a positive yet not a really significant influence on e-commerce satisfaction which is proven by t-statistic result that has less value than t-table result; $t$-statistic < t-table $(1.787<1.966)$ with $\mathrm{p}$-value of $0.037<0.05$. With this result, it can be concluded that e-commerce service information quality indicators such as the facilitation of purchasing one product and service offered, the availability of relevant information about the product and service offered, and the ease of completing every transaction on Tokopedia may affect the satisfaction of the customer.

Based on the $4^{\text {th }}$ hypothesis $(\mathrm{H} 4)$ result, e-commerce service information quality does not have a positive influence on e-commerce trust. This is proven by t-statistic result that has less value than t-table result; t-statistic $<$ t-table $(0.140<1.966)$ with $\mathrm{p}$-value of $0.444<0.05$. This result does not fit with the previous research conducted by Nasimi (2018). It can be concluded that e-commerce service information quality indicators such as the facilitation of purchasing one product and service offered, the availability of relevant information about the product and service offered, and the ease of completing every transaction on Tokopedia do not affect the customer trust.

Based on the $5^{\text {th }}$ hypothesis (H5) result, perceived security does not have a positive effect on ecommerce satisfaction as it is proven by the result of t-statistic < t-table $(0.245<1.966)$ and $p$-value of $0.403>$ 0.05. This result does not fit with the previous research conducted by Nasimi et al. (2018). According to this, it can be concluded that perceived security indicators such as a mechanism to ensure the safety of customer's personal information, an adequate technical capacity that data cannot be modified by hacker, financial risk, and a secure payment on Tokopedia does not affect the customer's satisfaction.

According to the $6^{\text {th }}$ hypothesis (H6) result, perceived security does not have a positive effect on ecommerce trust as it is proven by the result of t-statistic < t-table $(0.568<1.966)$ and $\mathrm{p}$-value of $0.285>0.05$. This result does not fit with the previous research conducted by Nasimi et al. (2018) and Vega, J., A (2015). It can be concluded that perceived security indicators such as a mechanism to ensure the safety of customer's personal information, an adequate technical capacity that data cannot be modified by hacker, financial risk, and a secure payment on Tokopedia does not affect the customer's trust.

Referring to the $7^{\text {th }}$ hypothesis (H7), e-commerce customer feedback does not have a positive effect on e-commerce satisfaction. It is proven by the result of t-statistic < t-table $(1.542<1.966)$ and p-value of $0.062>$ 0.05 . This result does not fit with the previous research conducted by Nasimi et al. (2018). It also concludes that e-commerce customer feedback indicators such as the availability of valuable information, user-friendly ecommerce, aesthetically interesting, and non-opportunistic do not affect Tokopedia's customer level of satisfaction.

The $8^{\text {th }}$ hypothesis (H8) result shows that e-commerce customer feedback does not have a positive effect on e-commerce trust and it is proven by the result of t-statistic < t-table $(1.057<1.966)$ and $p$-value of $0.146>0.05$. This result does not fit with the previous research conducted by Nasimi et al. (2018). It can be concluded that e-commerce customer feedback indicators such as the availability of valuable information, userfriendly e-commerce, aesthetically interesting, and non-opportunistic do not affect Tokopedia's customer trust.

The $9^{\text {th }}$ hypothesis (H9) testing result shows that perceived privacy has positive and significant influence on e-commerce satisfaction proven by the result of $t$-statistic value that is more than $t$-table value; $t$ statistic $>$ t-table $(8.658>1.966)$ and $p$-value of $0.000<0.05$. It concludes that perceived privacy indicators such as the secured personal information of customer, non-leaking information to the third party, a strong trust and security on customer's privacy may affect the satisfaction level of Tokopedia customer. 
DOI: $\underline{10.51386 / 25815946 / \text { ijsms-v4i3p118 }}$

Volume: 4 Issue: 3

May to June 2021

www.ijssmsjournal.org

According to the $10^{\text {th }}$ hypothesis (H10) testing result, it shows that perceived privacy has positive and significant influence on e-commerce trust proven by the result of $\mathrm{t}$-statistic value that is more than $\mathrm{t}$-table value; t-statistic > t-table $(6.283>1.966)$ and $p$-value of $0.000<0.05$. This result suits best with the previous research conducted by Vega, J., A (2015). It concludes that perceived privacy indicators such as the secured personal information of customer, non-leaking information to the third party, a strong trust and security on customer's privacy may affect the trust level of Tokopedia customer.

The $11^{\text {th }}$ hypothesis (H11) testing result shows that perceived risk has positive and significant influence on e-commerce satisfaction proven by the result of $\mathrm{t}$-statistic value that is more than $\mathrm{t}$-table value; $\mathrm{t}$-statistic $>\mathrm{t}$ table $(6.011>1.966)$ and $p$-value of $0.000<0.05$. It concludes that perceived risk indicators such as the nonrisky online purchase, the certainty of online purchase, and the sense of secured purchasing online on Tokopedia may affect the customer satisfaction.

The $12^{\text {th }}$ hypothesis (H12) testing result explains that perceived risk has positive and significant influence on e-commerce satisfaction proven by the result of $\mathrm{t}$-statistic value that is more than $\mathrm{t}$-table value; $\mathrm{t}$ statistic $>$ t-table $(10.449>1.966)$ and p-value of $0.000<0.05$. This result fits with the previous research conducted by Vega, J., A (2015). It concludes that perceived risk indicators such as the non-risky online purchase, the certainty of online purchase, and the sense of secured purchasing online on Tokopedia may affect the customer trust.

Based on the $13^{\text {th }}$ hypothesis (H13), perception of website quality has positive and significant influence on e-commerce satisfaction proven by the result of $\mathrm{t}$-statistic value that is more than $\mathrm{t}$-table value; $\mathrm{t}$-statistic $>\mathrm{t}$ table $(4.373>1.966)$ and $p$-value of $0.000<0.05$. It concludes that perception of website quality indicators such as the information of reliable product and service, the clear and accurate e-commerce design, the ability to pick up the good quality product on Tokopedia may affect the satisfaction level of the customer.

The $14^{\text {th }}$ hypothesis $(\mathrm{H} 14)$ testing result shows that perception of website quality has positive and significant influence on e-commerce trust proven by the result of $\mathrm{t}$-statistic value that is more than $\mathrm{t}$-table value; t-statistic $>$ t-table $(4.545>1.966)$ and $\mathrm{p}$-value of $0.000<0.05$. This result fits with the previous research conducted by Vega, J., A (2015). It concludes that perception of website quality indicators such as the information of reliable product and service, the clear and accurate e-commerce design, the ability to pick up the good quality product on Tokopedia may affect the customer trust.

Based on the $15^{\text {th }}$ hypothesis (H15) result, e-commerce satisfaction does not have a positive and significant influence on e-commerce loyalty. This is proven by t-statistic result that has less value than t-table result; $\mathrm{t}$-statistic $<\mathrm{t}$-table $(0.306<1.966)$ with $\mathrm{p}$-value of $0.380<0.05$. This result does not fit with the previous research conducted by Nasimi et al. (2018). It can be concluded that e-commerce satisfaction indicators such as the performance that meets the expectation, the sufficient experience of the company's marketing events, the company that recognizes the customer's needs, and the adequate resources needed in order to successfully running the activities on Tokopedia does not affect the customer loyalty.

Based on the $16^{\text {th }}$ hypothesis (H16) result, e-commerce trust has a positive and significant influence on e-commerce loyalty. This is proven by t-statistic result that has more value than t-table result; $t$-statistic $>t$-table $(12.783<1.966)$ with $\mathrm{p}$-value of $0.000<0.05$. This result suits best with the previous research conducted by Nasimi et al. (2018). It can be concluded that e-commerce trust indicators such as trustworthy and honest company, a company that holds the promise and commitment the strongest, the sense of secure when the customer is giving out their personal information and credit card number on Tokopedia may affect the loyalty of the customer.

\section{VI.CONCLUSIONS}

According to the overall result and discussion of this research, it is safe to conclude that several variables may have positive effect on the dependent variables. When Tokopedia service user interface shows an improvement, the customer satisfaction and loyalty will increase. The better the service information quality of Tokopedia, the higher the satisfaction of the customer will be. The better the perceived privacy felt by the customer, the higher the satisfaction level of the customer will be. When it comes to risk management, the better it becomes, the higher the satisfaction and trust of the customer. The better the perception of website quality of 


\section{DOI: $\underline{10.51386 / 25815946 / i j s m s-v 4 i 3 p 118}$}

Tokopedia, the higher the satisfaction and trust of the customer and when the trust is high, it goes the same with the loyalty of the customer.

\section{REFERENCES}

[1] Aggarwal, A., and Rahul, M. (2018). The effect of perceived security on consumer purchase intensions in electronic commerce. Int. J. Public Sector Performance Management, 1-20.

[2] Asosiasi Penyelenggara Jasa Internet Indonesia. (2018). Penetrasi dan profil pengguna internet di Indonesia. Jakarta: APJII.

[3] Eid, M. I. (2011). Determinants of e-Commerce Customer Satisfaction, Trust, and Loyalty in Saudi Arabia. Journal of Electronic Commerce Research, 78-93.

[4] Erickson, G. S., and Eckrich, D. W. (2001). Consumer affairs responnses to unsolicited consumer compliments. Journal of Marketing Management, 321-340.

[5] Evanschitzky, H., Gopalkrishnan, Hesse, J., \& Ahlert, D. (2004). E-satisfaction: a re-examination. Journal of Retailing, 239-247.

[6] Fadillah, M, Y., and Rachmawati, I. (2020). The Effect of Service Quality on Loyalty of Tri Indonesia Cellular Operator. International Journal of Science and Management Studies, 20-26.

[7] Flavian, C., and Guinnaliu, M. (2006). Consumer trust, perceived security and privacy policy: Three basic elements of loyalty to a web site. Industrial Management \& Data Systems, 601-620.

[8] Gao, J., Zhang, C., Wang, Ke., Ba, S. (2012). Understanding online purchase decision making: The effects of unconscious thought, information quality, and, information quantity. Decision Support Systems, 772-781.

[9] Gummerus, J., Liljander, V., Pura, M., and Riel, A, V. (2004). Customer loyalty to content-based Web sites: the case of an online health-care service. Journal of Services Marketing, 175-186.

[10] Haryono, S. (2017). Metode SEM untuk Penelitian Manajemen dengan AMOS LISREL PLS. Jakarta: Luxima Metro Media.

[11] Hermawan. (2019, 8 Juli). Kenali Pengertian Internet Beserta Fungsi, Fasilitas dan Manfaat Internet (Lengkap). [online]. Available: https://www.nesabamedia.com/pengertian-fungsi-dan-manfaat-internet-lengkap/ [28 Oktober 2020]

[12] Hidayat, A., Saifullah, M., and Ishak, A. (2016). Determinants of Satisfaction, Trust, and Loyalty of Indonesian E-Commerce Customer. Int. Journal of Economics and Management, 151-166.

[13] Jayani, D, H. (2019). Tokopedia, E-Commerce dengan Nilai Transaksi Terbesar. [online]. Available: https://databoks.katadata.co.id/datapublish/2019/10/15/2014-2023-nilai-transaksi-tokopedia-terbesar-dibandingkan-e-commercelainnya [30 Oktober 2020]

[14] Kotler, P. T., and Keller, K. L. (2009). Manajemen Pemasaran. (Edisi 13 Jilid 1). Jakarta: Erlangga.

[15] Kotler, P., and Keller, K.L. (2016). Manajemen Pemasaran. Jakarta: Erlangga.

[16] Lee, I. (2016). Encyclopedia of E-Commerce Development, Implementation, and Management (Edisi 1). USA: IGI Global.

[17] Mowen, J., and Minor, M. (2002). Perilaku Konsumen. Jakarta: Erlangga.

[18] Nancy, Y. (2019, 13 November). Pengertian, Fungsi, \& Perbedaan Internet, Intranet, dan Ekstranet. [online]. Available: https://tirto.id/pengertian-fungsi-perbedaan-internet-intranet-dan-ekstranet-ely8 [28 Oktober 2020]

[19] Nasimi, A, N., Nasimi, R, N., and Basit, R, A. (2018). Factors Affecting E-Commerce Customer Loyalty in Pakistan. Journal of Marketinng and Consumer Research, 17-30.

[20] Nurhayati, H. (2020). Distribution of e-commerce users in Indonesia in 2019, by city. [online]. Available: https://www.statista.com/statistics/1115215/indonesia-ecommerce-users-by-city/ [15 Maret 2021]

[21] Suryani, T. (2008). Perilaku Konsumen: Implikasi Pada Strategi Pemasaran. Yogyakarta: Graha Ilmu.

[22] Vega, J. A. (2015). Determiners of Consumer Trust towards Electronic Commerce: An Application to Puerto Rico. Esic Market Economics and Business Journal, 125-147. 